\title{
Maintaining (Environmental) Capital Intact
}

\section{Citation}

Rothschild, Emma. 2011. “Maintaining (Environmental) Capital Intact." Modern Intellectual History 8, no. 01: 193-212.

\section{Published Version}

doi:10.1017/S1479244311000114

\section{Permanent link}

http://nrs.harvard.edu/urn-3:HUL.InstRepos:12967688

\section{Terms of Use}

This article was downloaded from Harvard University's DASH repository, and is made available under the terms and conditions applicable to Other Posted Material, as set forth at http:// nrs.harvard.edu/urn-3:HUL.InstRepos:dash.current.terms-of-use\#LAA

\section{Share Your Story}

The Harvard community has made this article openly available.

Please share how this access benefits you. Submit a story.

\section{Accessibility}




\title{
Modern Intellectual History
}

http://journals.cambridge.org/MIH

Additional services for Modern Intellectual

\section{History:}

Email alerts: $\underline{\text { Click here }}$

Subscriptions: Click here

Commercial reprints: $\underline{\text { Click here }}$

Terms of use : $\underline{\text { Click here }}$

\section{MAINTAINING (ENVIRONMENTAL) CAPITAL INTACT}

\author{
EMMA ROTHSCHILD
}

Modern Intellectual History / Volume 8 / Issue 01 / April 2011, pp 193 - 212

DOI: 10.1017/S1479244311000114, Published online: 03 March 2011

Link to this article: http://journals.cambridge.org/abstract S1479244311000114

How to cite this article:

EMMA ROTHSCHILD (2011). MAINTAINING (ENVIRONMENTAL) CAPITAL

INTACT. Modern Intellectual History, 8, pp 193-212 doi:10.1017/

S1479244311000114

Request Permissions : $\underline{\text { Click here }}$ 


\section{MAINTAINING (ENVIRONMENTAL) CAPITAL INTACT ${ }^{*}$}

\section{EMMA ROTHSCHILD}

Department of History, Harvard University, and Joint Center for History and Economics E-mail: er10005@cam.ac.uk

The idea of sustainability is an odd composite of imagination and accounting. Environmental history is a permissive historical subdiscipline, and this essay is about the environmental-economic-intellectual history of an environmental idea, sustainability, which is historical in the sense that it is very old, and historical, too, in the sense that it is an idea about history, or about imagining the future in relation to the past. ${ }^{1}$ One of the oddities of the last several decades is that these old ideas have been transformed into the most celebrated of all the dicta of environmental policy, or an aspiration of UN commissions, "strategy consultancies", and very large government agencies ("sustainability is our 'true north.'”')

I will be concerned, within this long and intricate story, with the history of one particular simile or understanding of sustainability, in which nature, or the environment, is seen as being like a capital stock, and the responsibility of sustainability, in turn, is an injunction to maintain intact the value of an

* Earlier versions of this essay were presented at the Department of Economics, University College London, in 1994, at the Center for History and Economics, Harvard University, in 2008, and at the Seminar on Measurement and Well-Being at the London School of Economics in 2010. I am most grateful to Tony Atkinson, Aditya Balasubramanian, David Blackbourn, Nancy Cartwright, Alison Frank, Walter Johnson, Dale Jorgenson, Tony La Vopa, Harriet Ritvo, Charles Rosenberg, Amartya Sen, Aubrey Silberston, Sverker Sörlin, Adrian Vermeule and Paul Warde for helpful discussions.

$1 \quad$ Sverker Sörlin and Paul Warde, "The Problem of the Problem of Environmental History: A Re-reading of the Field", Environmental History 12/1 (Jan. 2007), 107-30.

2 On the UN's "Millennium Goal" number 7, "ENSURE ENVIRONMENTAL SUSTAINABILITY", see http://www.un.org/millenniumgoals/environ.shtml; on "transformative business leadership on the sustainability agenda", see http://www.sustainability.com; on the "goal of sustainability" as the true north of the US government's Environmental Protection Agency, see http://www.epa.gov/sustainability; and on the EPA's budget, see http://www.epa.gov/ocfo/budget/2011/2011bib.pdf, all accessed 2 Oct. 2010. 
"appropriately defined" stock of natural or environmental capital. ${ }^{3}$ Even this simile is not particularly new, and there is a wonderful conversation between a gnome and a sprite, in a dialogue published in 1827 by the Italian poet Giacomo Leopardi, set in a future time when all men have died. The gnome wishes that one or two men might be reborn, just for the pleasure of observing them when they realize that everything was going on as before, "while they had believed that the entire world was made and kept alive for them alone". Men "from time to time discovered some star or some planet", the sprite says, and "immediately they made it figure in the inventory of their household property, because they imagined that the stars and the planets were lamps and candles, so to speak, placed up in the sky in order to illuminate their lordly homes". But when the men are gone, "the rivers are not tired of flowing; and even though it no longer serves for navigation and traffic, the sea does not seem to have dried up". "The stars and the planets have not stopped rising and setting", says the gnome; "they are not in mourning" for men. ${ }^{4}$

\section{CAPITAL AND VALUE}

The version of the old figure of speech with which I will be concerned is newer, and less lyrical. The modern political importance of the ideas of sustainability and sustainable development began, on a large scale, with the publication in 1987 of Our Common Future, the report of the Commission on Environment and Development, chaired by the Norwegian prime minister Gro Harlem Brundtland, with its definition of sustainable development as "development that meets the needs of the present without compromising the ability of future generations to meet their own needs". It is this objective which has been so widely interpreted as the injunction to maintain (environmental) capital intact. It is "a useful rule of thumb for policy", in the economist Robert Solow's words, to think of "an appropriately defined stock of capital—including the initial endowment of resources-[as] being maintained intact", and of consumption "as the interest on that patrimony". 6 Sustainability, it is suggested, is an idea about capital, and

3 Robert M. Solow, "On the Intergenerational Allocation of Natural Resources", Scandinavian Journal of Economics 88/1 (March 1986), 141-9, 141.

4 Giacomo Leopardi, "Dialogo di un folletto e di uno gnomo", in idem, Operette Morali (Milan, 1976; first published 1827), 81-5.

5 World Commission on Environment and Development, Our Common Future (Oxford, 1987), 42.

6 Solow, "On the Intergenerational Allocation of Natural Resources", 141. 
two prominent economists have indeed referred to "Environmental Economics As Capital Theory"'?

The historical story I want to tell has to do with the mid-twentieth-century origins of these ideas, in the economic disputes of the 1930s and 1940s over "maintaining capital intact". The disputes were of a fairly theoretical sort, and they had little to do with natural or environmental capital. ${ }^{8}$ They were widely described, in the post-war period, as "old-fashioned", "abstruse", "very difficult", or "most controversial". 9 The route by which they came to influence the ideas and institutions of subsequent environmental policy was indirect. But the journey is of interest for intellectual and environmental history, as I will suggest. It is also a journey into some of the most profound political choices of the times, to do with the nature of (national or international) power, the relationship between economic theory and economic circumstances, and the politics of public information.

The controversy over maintaining capital intact culminated in 1941 and 1942, and the protagonists were three English economists, A. C. Pigou, Friedrich Hayek (who had become a naturalized British subject in 1938) and John Hicks. It is only Hicks, of the three, who was in any respect prominent in later discussions of augmented or environmental accounts and sustainability, as the inventor, in 1939, of "Hicksian income", identified as "the maximum amount that can be consumed while leaving capital intact". ${ }^{10}$ Pigou was at the time "the dean of theoretical economics in the world today", in the Chicago economist Frank

$7 \quad$ Partha Dasgupta and Karl-Goran Mäler, Poverty, Institutions, and the EnvironmentalResource Base (World Bank Environment Paper no. 9, The World Bank, 1994), 9. "The quality of the environment is part of our capital stock, just like bridges and buildings. There is every reason to treat the environment along with other capital as a relevant input in a firm's production function." Barry Nalebuff, "On a Clear Day, You Can See the Coase Theorem”, in Partha Dasgupta and Karl-Goran Mäler, eds., The Environment and Emerging Development Issues, vol. 1 (Oxford, 1997), 35-47, 38.

8 A. C. Pigou, in 1935, considered the possibility of including "stores of coal, minerals, oil and so on that Nature has laid up" in estimates of national or social capital; Frank Knight speculated about the future circumstances that "coal is replaced by oil or by hydraulic power, not to mention wider possibilities of substitution”. A.C. Pigou, The Economics of Stationary States (London, 1935), 22; Frank H. Knight, "Some Issues in the Economics of Stationary States”, American Economic Review 26/3 (Sept. 1936), 393-411, 400-401.

9 Solow, "On the Intergenerational Allocation of Natural Resources", 149; G.K. Goundrey, "Economics and Conservation", Canadian Journal of Economics and Political Science 26/2 (May 1960), 319-25, 322; Richard Ruggles, "Concepts, Sources, and Methods of United States National Income Accounts”, Econometrica 20/3 (July 1952), 467-71, 469.

$10 \quad$ William D. Nordhaus and Edward C. Kokkelenberg, eds., Nature's Numbers: Expanding the U.S. National Economic Accounts to Include the Environment (Washington, DC, 1999), $183-4,190$. 
Knight's description, although with an enduring aspiration, in his own selfdescription, to free himself from the "appearance of fine-drawn academic subtlety, by which the practical man is so apt to be repelled"; he was the leading figure in the economics of welfare, and of what was later described as "market failure". "Hayek, four years before the publication of The Road to Serfdom, was known, for the most part, as a pure theorist of capital, although disposed, as The Economist wrote in March 1941, to disputation with "his compeers-too many of whom, in Professor Hayek's view, have committed an intellectual error, betrayed their duty, and even 'menaced civilisation."'12

The controversy of 1941-2 unfolded in the journal of the London School of Economics, Economica, which had at the time been evacuated from London to Cambridge; the cover bore the notice "War-Time Address: The Hostel, Peterhouse, Cambridge". Hayek, who was the editor and principal contributor, was evacuated, too, in the odd episode in intellectual history in which Hayek and John Maynard Keynes served together as fire wardens, in long nights of conversation on the roof of King's College Chapel. ${ }^{13}$ The particular controversy was concerned with "maintaining capital intact" in the limited sense of whether the income of an individual (or society) in a particular period should be thought of as net of the addition to or depletion of the individual's (or society's) wealth over the same period: of whether the individual had become "impoverished". There was no explicit implication, as in later concepts of sustainable income, of evaluating the netness of income in relation to the possibility of future income, over a finite or an infinite posterity. The controversy was rather over how to think about and measure income in a particular period; and even, as one of Pigou's earlier critics had objected, over the "somewhat curious" objective of "making real income correspond with income returnable for taxation, meaning of course under the laws of Great Britain at the time of writing". ${ }^{4}$

Of the three protagonists in the controversy, Pigou was the closest to the modern conceptions which are embodied in the augmented or environmental

11 A. C. Pigou, "A Parallel between Economic and Political Theory", Economic Journal 12/46 (June 1902), 274-7, 277; Knight, "Some Issues in the Economics of Stationary States", 393. The word "practical" appears in forty-eight of the eighty-two articles by Pigou in the JSTOR database.

12 "Shorter Notices, 'The Pure Theory of Capital", The Economist, 1 March 1941, 276.

13 Cover page, Economica new ser., 8/31 (Aug. 1941); oral communication by the late Dr Larry Hayek, conference on The Road to Serfdom, Centre for History and Economics, King's College, Cambridge, 2004; and see Melissa Lane, "Friedrich von Hayek and The Road to Serfdom: 1944-2004", available at http://www-histecon.kings.cam.ac.uk/ events/hayek_report.pdf.

14 Knight, "Some Issues in the Economics of Stationary States", 402 n. 12. 
accounts of the late twentieth century. ${ }^{15} \mathrm{He}$ argued that "capital consists at any given moment of a definite inventory of physical things", that the concept of maintaining capital intact was "needed" by "practical" men, and that capital was maintained intact over a period of time either when its "physical constituents [are] unaltered" or when any altered item was replaced by another item which was "worth" ("is expected to yield the same income as") the same. ${ }^{16}$

Hayek denied that Pigou's procedure could have "any practical value or any theoretical significance". It was essential, in Hayek's view, to get inside the mind of the entrepreneur. "No watching of the 'quantity' of his capital from the outside" would suffice: "In a changing world, where different people, and even the same people at different times, will possess different knowledge, there can be no objective standards" for judging the success of the entrepreneur in maintaining his "sources of income". 17

Hicks "came down mainly on Hayek's side", and argued that the principle of maintaining capital intact would lead to measurements which were "internally inconsistent", because "the beginning-value and the end-value were arrived at on a different basis of knowledge". But Hicks thought that Hayek's theory was not "usable in practice". He also surmised that Pigou and Hayek were thinking about different things: that only Pigou, at least, was concerned with net social income, or the income of the society as a whole, and its measurement "as a means of comparing economic welfare in different periods". He conceded later that "statisticians, asked to measure National Capital", had continued to rely on "volume" or "Materialist" conceptions: "it is a major complication, which oppresses the statistician ... that the expectations of individuals are not harmonious". The place of "value" measures, he concluded, was in "theoretical analysis". ${ }^{18}$

The 1941-2 debate was not resolved in any sort of consensus. Of the three very large issues raised in the course of the controversy-having to do with the heterogeneity of objects of value, the "inside" nature or insideness of values, and the identity of the valuers (whoever it was that was doing the evaluation, and for what reason) - it was only the first that was of some continuing interest to economists. Thirty years later John Hicks wrote that the debates of the period

15 On augmented accounts see Nordhaus and Kokkelenberg, Nature's Numbers, 183, 185, 188, 190.

16 A. C. Pigou, "Maintaining Capital Intact", Economica new ser., 8/31 (Aug. 1941), 271-5.

17 F. A. v. Hayek, "Maintaining Capital Intact: A Reply", Economica new ser., 8/31 (Aug. 1941), $276-80$.

18 J. R. Hicks, "Maintaining Capital Intact: A Further Suggestion”, Economica new ser., 9/32 (May 1942), 174-9; idem, "Capital Controversies: Ancient and Modern", American Economic Review 64/2 (May 1974), 307-16, 309, 315 n. 14; idem, Capital and Time: A Neo-Austrian Theory (Oxford, 1987), 163. 
"have never been wholly stilled"; "much of the main modern controversy about capital", he said, "is just the old controversy in a new guise". ${ }^{19}$ Neither Hayek nor Pigou returned directly to the original dispute. Pigou remained committed to the notion of an "aggregate volume of productive resources", notably in his work on real income comparisons. For Hayek, the idea of "inside knowledge" was of central importance in the development, later in the 1940s, of a subjective theory of value, and of his theory of knowledge in society. In a very sweeping panorama of the intellectual history of twentieth-century economics, it as though two imposing processions encountered each other, briefly, and passed on.

\section{REMINDERS OF OLD IDEAS}

It was these old ideas of maintaining capital intact that were rediscovered, in different form, in the 1970s. The Yale economists William Nordhaus and James Tobin, in 1972, introduced the idea of a "sustainable MEW", or "measure of economic welfare", in their outline of a revision of national-income accounts, Is Growth Obsolete?, addressed to "both growth men and antigrowth men". In it, they added estimates of the "disamenities of urban life", "regrettables" such as national defence, and the services of stocks of consumer capital, to the conventional calculation of net national product as "the amount of consumption that leaves the capital stock 'intact.'”20 The economist Martin Weitzman, in 1976, included natural resources in the capital stock; "pools of exhaustible natural resources ought to qualify as capital". ${ }^{21}$ Robert M. Solow, in a lecture given in Uppsala in 1984 that is the most celebrated source, among writings by economists, of the idea of sustainable development, concluded that "allowable consumption" could be interpreted as "the interest on an initial patrimony or resource endowment", or on "an appropriately defined stock of capital including the initial endowment of resources". It was "a reminder of the old-fashioned obligation to 'maintain capital intact."'22

The idea of a stock of environmental-natural capital was embodied, over the following decades, in a practical enterprise of constructing augmented or satellite national accounts. This was a "parallel effort among economists", in the expression of a report called Nature's Numbers, prepared for the US

19 John Hicks, Classics and Moderns (Cambridge, MA, 1983), 96-7.

20 William Nordhaus and James Tobin, Is Growth Obsolete?, in National Bureau of Economic Research, Economic Research: Retrospect and Prospect, Economic Growth, Fiftieth Anniversary Colloquium (New York, 1972), 24, 34.

${ }^{21}$ Martin L. Weitzman, "On the Welfare Significance of National Product in a Dynamic Economy”, Quarterly Journal of Economics 9o/1 (Feb. 1976), 156-62, 157.

22 Solow, "On the Intergenerational Allocation of Natural Resources", 149. 
National Research Council in 1999, to develop "measures of national income and output that take notions of sustainability into account", in particular by arriving at an "augmented" or "broader definition of 'capital," or of the "stocks of capital and other dynamic features that affect production". The estimate of national capital was to be "corrected", in these measures, by including human capital (or the capital embodied in individuals), government capital, the stock of research and development, and "natural capital such as forests, mineral resources, and environmental resources". 23 The "correct measure" was itself "rooted in traditional capital theory". ${ }^{24}$

Capital accounts in general, and the accounts for augmented or natural capital in particular, became, in the course of the 1990s, one of the enduring preoccupations of national (and international) statistical offices, and one of the ways in which even high or abstract economic theory was incorporated in the measurement of ordinary life. The implementation of the successive systems of accounts produced by the UN Statistical Office thus came to involve the finest details of national life. ${ }^{25}$ The Australian National Accounts, for example, provided an elaborate illustration of the revision of capital accounts, in the treatment of activities from "speculative construction" to "rockets, missiles, warheads", and from "historic monuments" of "special value" ("'special' in this case referring to cultural, historical, religious and archaeological significance") to "purchased goodwill" and "internally generated non-produced intangibles". ${ }^{26}$

An investigation of stocks of natural or environmental capital commissioned on behalf of the Department of Economic Affairs of Namibia was an even more vivid illustration of the new universe of numbers. There was an estimate of the stocks of hake, horse mackerel and pilchard. There were "physical accounts for land", or the prospect of physical accounts, but no "monetary accounts", or valuations, because "no market prices exist for the very large portions of the land that are subject to traditional communal tenure regimes". There were estimates of the stocks of diamonds, uranium and gold, and the dispiriting conclusion that

23 Nordhaus and Kokkelenberg, Nature's Numbers, 183, 185, 188, 190.

24 John M. Hartwick, "Natural Resources, National Accounting and Economic Depreciation", Journal of Public Economics 43 (Dec. 1990), 291-304, 301.

25 On the UN System of National Accounts of 1993 and the System of Integrated Environmental and Economic Accounting of 2002, see Searchable Archive of Publications on Environmental-Economic Accounting, available at http://unstats.un.org/unsd/ envaccounting/ceea/archive/Introduction.asp; and Integrated Environmental and Economic Accounting 2003 (SEEA 2003), available at http://unstats.un.org/unsd/ envaccounting/seea.asp.

26 Canberra Group on Capital Stock Statistics-November 1999 meeting, unpaginated, available at http://www.oecd.org/document/49/o,3343,en_2825_500246_1876337_ 1_1_1_1,oo.html. 
the "mineral assets" of Namibia had lost " 55 percent of their asset value from 1980 to $2000 "{ }^{27}$

The economists' ideas of sustainability were rediscovered, too, or reinvented, in the new environmental policies of the period following the presentation of the Brundtland Report at the UN Rio de Janeiro Conference on Environment and Development in 1992. "Sustainable development" and "sustainability" became the names, or organizing principles, of a new transnational and incipiently post-national venture, part public, part private; the most successful of all the new dicta, the "big, impractical words", in Daniel Rodgers's description, which became so practicable, or practisable, in the late twentieth-century expansion of commissions, institutes, newsletters, prizes, agencies, foundations, consultancies and expert committees. "Human development", "common security", "human security", "sustainable development" —of all these "UN words" and global phrases, "sustainability" was by far the most visible, mentioned, in October 2010 , in $36,900,000$ websites, with an additional $21,400,000$ for "sustainable development". ${ }^{28}$

Sustainable development even came to be known, from time to time, by the alias "Brundtland-Solow", as in "sustainability à la Brundtland-Solow", or the "Brundtland-Solow standard", or even "the BS standard" ${ }^{29}$ But the large aspirations of the new institutions were very different indeed, by the late twentieth century, from the economists' ideas of the 1980 os (or the 1940s). Sustainability had become a maxim of policy, or an exhortation. The UN's official website in respect of the Rio Conference explained its objectives in imposing terms: "the Summit's message is that nothing less than a transformation of our attitudes and behaviour would bring about the necessary changes". ${ }^{0}$ There were "96 Indicators of Sustainable Development", described as "tools to communicate ideas, thoughts and values", to be used for "both communicating with and raising

27 Glenn-Marie Lange, "National Wealth, Natural Capital and Sustainable Development in Namibia”, DEA research discussion paper no. 56, Feb. 2003, Windhoek, Namibia, 6-8, 10; available at http://www.met.gov.na/publications/research/RDP56.pdf.

28 Daniel T. Rodgers, Contested Truths: Keywords in American Politics since Independence (Cambridge, MA, 1998), 7; Google search, 2 Oct. 2010. On "UN words" see Emma Rothschild, "The Archives of Universal History", Journal of World History 19/3 (Sept. 2008), 375-401.

29 Amartya Sen, "Why We Should Preserve the Spotted Owl", London Review of Books 26/3 (5 Feb. 2004); Gilles Paquet, "The Governance of Sustainability: A Social Learning Approach", undated, available at http://www.invenire.ca/Res_papers/Governance_ of_sustainability.pdf, accessed on Oct. 24, 2008.

30 See http://www.un.org/geninfo/bp/enviro.html, accessed 29 Oct. 2008. 
the awareness of the public" ${ }^{11}$ "Changing behaviour is a cross cutting theme", the British government's Department of Environment said of its own policies for sustainable development..$^{22}$ "As far as I can tell", Robert Solow lamented in 1992, "discussion of sustainability has been mainly an occasion for the expression of emotions and attitudes".33

\section{ECONOMIC IDEAS AND INTERMEDIATE MAXIMS}

The old-fashioned ideas of keeping capital intact had large and unexpected political consequences, in these respects, in late twentieth-century environmental policy. The destiny of Pigou's, Hayek's and Hicks's theory is an interesting illustration, in turn, of the arcs of ideas by which the high economic thought of eminent theorists is transposed into the "medium" thought of applied economists, statisticians, development experts and public officials, and into the "low" economic thought of the public whom the officials seek to influence (the $58,000,000$ people or so, counting one person per website, who are interested in sustainability and sustainable development.) It is an illustration, too, of the distances over which ideas travel, in time and space: from the pure theory of capital, to "Brundtland-Solow", the UN System of Statistical Accounts, and the evaluation of Namibian pilchards. ${ }^{34}$

"The practical value of the science of political economy ... lies in its 'middle principles' [or] intermediate maxims", the economic commentator Walter Bagehot wrote in 1860, in an obituary of his father-in-law, the founder of The Economist. ${ }^{35}$ A generation later, the profession of economics had become a large and practical enterprise. Arthur Hadley, the Yale law professor and president of the American Economic Association, wrote in his turn-of-the-century address, in 1899, that "at no previous period has popular interest in the subject been so widespread"; "in education, in journalism, or in finance, the trained economist

31 United Nations Commission on Sustainable Development, Indicators of Sustainable Development: Guidelines and Methodologies, 3rd edn (New York, 2007), 3, 9, 40.

32 See http://www.defra.gov.uk/sustainable/government/what/index.htm, accessed 19 Dec. 2009.

33 Robert M. Solow, An Almost Practical Step toward Sustainability (Washington, DC, 1992), 14.

34 See Emma Rothschild, "Arcs of Ideas: International History and Intellectual History", in Gunilla Budde, Sebastian Conrad and Oliver Janz, eds., Transnationale Geschichte: Themen, Tendenzen und Theorien (Göttingen, 2006), 217-26.

35 Walter Bagehot, "Memoir of the Right Honourable James Wilson", The Economist, 17 Nov. 1860, 1287-1300, 1289, original emphasis. 
to-day finds a great and growing demand for his services" ${ }^{36}$ For Pigou, after another generation, "economic argument [was] coming continually to play a larger and larger part in partisan political debate", to the extent, by 1935, that economic theorists were "in continual danger" of "attempts at exploitation". 37 The history of ideas about environmental capital is in this sense a history of the many lives of economists in the twentieth century, and of the many destinies of their ideas. There was an orderly process, in principle, by which the theoretical or abstract ideas of the most eminent economists_- "heroically theoretical", in an early twentieth-century expression-were cast into the ether of intellectual life, and were exploited there by economists of different sorts, in different circumstances; the theorists themselves were not, in this view of the intellectual division of labour, the sources of popular ideas. ${ }^{38}$

All the protagonists in the capital-theory disputes of the 1930 and 1940 s were intensely conscious of these transformations of ideas, or of the complicated, changing relationships between economic theory and economic policy, and between their own theories and their observations of the world. 39 "In a rough general way the concept 'maintaining capital intact' is easy to grasp", Pigou wrote in 1941. He ended with a passage of spectacularly mixed metaphors, in respect of the correspondence between the ideas of economic theorists and the "practical use" of economic distinctions:

We do not want to spend our lives in squaring the circle ... [We cannot] evolve concepts which are perfectly clean cut. There are bound to be rough edges ... [We] have tried our hand at smoothing these down ... We have not, I suggest, failed so grievously that others, instead of giving our baby another wash, should empty both it and the bath away. ${ }^{40}$

The ideas of economists were expected to correspond, in an approximate way, with the ideas of the "plain man", and with the ideas embodied in public laws and institutions (including the tax code)..$^{41}$ Ideas about the income of individuals were expected to correspond with ideas of the income of societies, or countries. The ideas of plain or ordinary men were at the same time both influenced by and an influence on public institutions; they were even influenced by the ideas of

36 Arthur T. Hadley, "The Relation between Economics and Politics", Yale Law Journal 8/4 (Jan. 1899), 194-206, 194-5.

37 A. C. Pigou, Economics in Practice: Six Lectures on Current Issues (London, 1935), 8-9.

38 J. B. Clark, "The Future of Economic Theory", Quarterly Journal of Economics 13/1 (Oct. 1898), 1-14, 9.

39 As Frank Knight observed, "the relationship of theory to action is perhaps peculiarly obscure" in respect of the theory of capital and interest. F. H. Knight, "Professor Mises and the Theory of Capital", Economica new ser., 8/32 (Nov. 1941), 409-27, 410.

40 Pigou, "Maintaining Capital Intact", 275.

41 A. C. Pigou, The Economics of Welfare, 3rd edn (Cambridge, 1928), lxviii. 
economists. The economists' own ideas were influenced by their observations of a real economic (and institutional) world which changed continuously over time. The objectives of public institutions also changed over time, with the evolution of political and economic circumstances. So did the ways in which economists expressed their ideas, over the course of their lifetimes and ways of life. Even the loftiest of economic intellectuals were participants in public life. Pigou described Keynes, censoriously, as "one whose vividness of phrase has made him a valued contributor to the Daily Mail', and confessed that he had himself written an article in the Sunday Express. ${ }^{42}$

The idea of maintaining capital intact was a particularly transitory and transitional objective. Pigou had initially, in his writings on capital, proceeded from an idea of business income, or of the income of an individual entrepreneur, as conceived from the point of view of the "income tax authorities". This was even his own point of view, to the extent that he had first come into public prominence, during the First World War, as a commentator on the principles of income tax, and had subsequently served as a member of a Royal Commission on Income Tax. But his preoccupations had clearly evolved, with the depression of the 1930 s and the exigencies of the Second World War, to a concern by 1941-2, as Hicks discerned, with net social income, or the income of nations, and its measurement "as a means of comparing economic welfare in different periods". ${ }^{43}$

The evaluation of national or social income was Hicks's concern as well, in the frightening wartime years during which the modern British, American and "international" (or UN) systems of national accounts were developed; as Hicks wrote in 1942, "comparing economic welfare is not the only purpose (nowadays, alas! it is not even the main purpose) of measuring the National Income". ${ }^{4}$ It was the wartime and post-war system of national or social accounts that evolved, in turn, into the extended accounts of the late twentieth century. The idea of Hicksian income, or income that leaves capital intact, was consolidated, in the new systems of national accounts of the 1940s, as a description of social as well as individual income, and a generalization of business income to the national income of the society. For the authors of Nature's Numbers, in 1999, Hicksian income was the "standard definition of NNP [net national product] used in the national accounts of virtually all nations today". ${ }^{45}$ It was this definition that was extended, in the 1970 s and 1980s, to include human, natural and environmental capital, and consolidated in new and augmented accounts.

A. C. Pigou, "Mr. J. M. Keynes' General Theory of Employment, Interest and Money", Economica new ser., 3/10 (May 1936), 115-32, 119.

43 Hicks, "Maintaining capital intact", 179.

44 Ibid., 179.

45 Nordhaus and Kokkelenberg, Nature's Numbers, 183, 190. 
The relationship between economic ideas and their eventual "exploitation" in policy was indirect, for the economists of the 1970s and 1980s, as it had been for Pigou in 1935. The idea of sustainable welfare, like the earlier ideas of the capital theorists, was in this spirit assertively impractical; Nordhaus and Tobin spoke of "heroic aggregation", and Weitzman of "extreme abstraction"; "we abstract heroically" ${ }^{46}$ The ideas were thrown out, as it were, into arcs of influence. The implicit depiction of the procedures of social or national accounting, as in the wartime and post-war controversies over capital, was of an orderly sequence of economists, applied economists and statisticians. Even Hicks referred to a statistician who "is asked to measure National Capital" by an unidentified interlocutor, and by whom measurements are "turned out", "for the use of applied economists". The authors of Nature's Numbers identified the object of their augmented accounts as something different from and more indistinct than policy: "scorekeeping or management".47 "One has to decide-whoever 'one' is - whether later generations are entitled to a higher standard of living", Robert Solow wrote in the Uppsala article about the appropriately defined stock of capital, and concluded, poignantly, that "there is something to be said for rules of thumb, for shorthand ways of taking care of interests that might otherwise be neglected". ${ }^{8}$

\section{A POLITICAL HISTORY OF ECONOMIC IDEAS}

The history of the long and indirect journey from Pigou and Hicks to the websites of the UN Division for Sustainable Development is a political story, in a number of respects. The simile of nature as capital, or of environmental capital, is itself political, in a rather obvious way. It is an interesting illustration of the audacity of the economic imagination: of the extent to which serious men and women, who influenced the policy of Namibia, or of the West Virginia coal industry, were able to conceive of themselves, and of others, as living in a world of capital stocks; in which everything is capital. In the summary of the authors of Nature's Numbers, "consumption is produced by a large number of different kinds of capital goods". 49 "The extreme abstraction [is made] that all sources of economic growth have been identified and attributed to one or another form of capital, broadly defined", Weitzman wrote in 1976, of his own variation of

46 Weitzman, "On the Welfare Significance of National Product in a Dynamic Economy", 156-7; Nordhaus and Tobin, Is Growth Obsolete?, 14.

47 Hicks, Capital and Time, 163; Nordhaus and Kokkelenberg, Nature's Numbers.

48 Solow, "On the Intergenerational Allocation of Natural Resources", 141, 148.

49 Nordhaus and Kokkelenberg, Nature's Numbers, 188. 
a "capital theory of value".50 An environmentalist study called Nature's Services spoke of "the goods and services flowing from natural ecosystems", which "are greatly undervalued by society". ${ }^{11}$ To be valued, in these views, is to be something like a thing: to be the sort of thing that is owned, or persists over time, or is itself something by which other things are produced. Social relations between men, as Karl Marx wrote in the first chapter of Capital, assumed "the fantastic form of a relation between things". ${ }^{2}$ The twentieth century, too, was a capital century.

But the political history of the idea of environmental capital did not correspond in any straightforward way, all the same, to a division between right and left, in economic thought, or between "classical", "neo-classical" and other economists. Pigou was the anti-hero of Keynes's General Theory of Employment, Interest and Money, the living representation of the "classical theory of unemployment", with its implication that unemployment is caused by "frictional resistances [to] appropriate wage adjustments". ${ }^{33} \mathrm{He}$ was an even more anti-heroic figure in Knight's, Hayek's and later R. H. Coase's critiques of the economics of welfare, with its excessive confidence in the wisdom of government, and its excessive anxiety over "market failure". He was the representation, in particular, of the "fallacy of social cost", or of the conception of the state as an entity intervening to increase national welfare, or national efficiency, rather than to "define and protect property rights, enforce contract and prevent ... collusion and monopoly, the antithesis of competition" ${ }^{44} \mathrm{He}$ was too confident in the efficiency of competition for Keynes, and too unsolicitous of competition for Knight. He was too modest and too grandiose in respect of the state.

These were the large, implicit and unresolved questions of the disputes over capital of 1941-2, and they returned in different form in the late twentiethcentury discussions of national or environmental capital. The question of the

50 Weitzman, "On the Welfare Significance of National Product in a Dynamic Economy", 156-7; idem, "Shiftable versus Non-shiftable Capital: A Synthesis", Econometrica 39/3 (May 1971), 511-28, 516.

51 Gretchen C. Daily, Nature's Services: Societal Dependence on Natural Ecosystems (Washington, DC, 1997), 2.

52 Karl Marx, Capital: A Critique of Political Economy, trans. Samuel Moore and Edward Aveling, vol. 1 (London, 1970; first published 1887), 72. "It is as though light of a particular hue were cast upon everything, tingeing all other colours and modifying their special features ... Capital is the economic power that dominates everything in bourgeois society." "Introduction to a Critique of Political Economy", in Karl Marx and Friedrich Engels, The German Ideology, ed. C.J. Arthur (New York, 1978), 146-7.

53 J. M. Keynes, The General Theory of Employment, Interest and Money (New York, 1964; first published 1936), 278-9.

54 F. H. Knight, "Some Fallacies in the Interpretation of Social Cost", Quarterly Journal of Economics 38/4 (Aug. 1924), 582-606, 606. 
heterogeneity of objects of value had virtually vanished, by the 1990s, from theories of conventional, or manufactured capital..$^{55}$ But the objects which would be likely to enter into a stock of natural-cum-manufactured capital were vastly more disparate in a physical sense, and in the sense of their expected persistence over future time (from genetically engineering bacilli to uranium deposits). They were more disparate, too, in the sorts of property rights with which they were associated, or in the modes in which they (or their services) were owned. They were owned (or valued) in one society, and of interest in other societies. "If factors of production are thought of as rights", as in the expression of R. H. Coase, then the property rights in pilchards and unproved diamond reserves, in the Namibian desert and the Uluru rock, were heterogeneous indeed - heterogeneous, in particular, in their proximity to near-market substitutes, and to the possibility of being evaluated on the basis of market or "shadow prices". 56

It was "society", in Pigou's and Hicks's conceptions of 1941-2, which had an interest in the evaluation of "net social income", and of national or social capital. It was society, too, which had the responsibility for the exercise of valuation or measurement: for identifying the disparate objects of value, or capital-like things, and for deciding on how they should be valued. For the authors of Nature's Numbers, the procedure would be discreet and unobtrusive. It would be a "monitoring of physical flows and valuation", within "existing regulatory analysis and enforcement", just as the measurement of economic flows is dependent on existing tax administration, including customs and excise enforcement. It would rely on "the market's estimate" of the future, rather than on the calculations of "a dream team of world-class researchers". ${ }^{77}$ But the exercise would be undertaken, all the same, on behalf of "society". It would be paid for by "society", or by the state, or even, in the case of the capital-like things which were heterogeneous in the sense of being owned in one society and of interest in other societies,

55 If the services of heterogeneous capital goods are aggregated on the basis of the "cost of capital", then the cost incorporates expectations about the future. See Dale W. Jorgenson, "Information Technology and the U.S. Economy", American Economic Review 91/1 (March 2001), 1-32.

56 R. H. Coase, "The Problem of Social Cost”, Journal of Law and Economics 3 (Oct. 1960), 1-44, 44; and see R. H. Coase and R. F. Fowler, "The Pig-Cycle in Great Britain: An Explanation", Economica new ser., 4/13 (Feb. 1937), 55-82, 80.

57 "Imagine for a moment that a dream team of world-class researchers is asked to analyze the important question of the impact on future living standards of the exhaustion of finite petroleum stocks". The report's conclusion was that in spite of a "large budget", and a "massive, dynamic, computable" model, the "dream research team" would be less credible than "the market's estimate". Nordhaus and Kokkelenberg, Nature's Numbers, 194, 196. 
by an international organization, or an international society, "at the global level". ${ }^{8}$

Hayek's second objection to Pigou, to do with the insideness of values, raised more profound difficulties. Hayek's evocation of a "changing world, where different people, and even the same people at different times, will possess different knowledge", was an anticipation of his celebrated denunciation, also in Economica, a few months later, of the "scientism" which seeks to look at societies "from the outside", and to exclude "our knowledge of the inside of these social complexes", of "what things mean to the acting men", or of "the intentions of the acting individuals". "The blind transfer of the striving for quantitative measurements", he wrote, had led to "assignments of numerical values which are absolutely meaningless". 59 It was an anticipation, too, of Hayek's eulogy to the dispersed or disparate knowledge, the local knowledge of millions of individuals, in opposition to the systemic knowledge of experts. The dominion of "suitably chosen experts" was itself a despotism. ${ }^{60}$

The enterprise of valuing environmental or natural capital was unavoidably, in these terms, an exercise in looking at society, or the universe, from the outside. The procedure for evaluating environmental capital would begin, in principle, with an approximation to what the economist Irving Fisher described as an "instantaneous photograph of wealth", of long-lived and fleeting things, things which were living and things which had never lived, owned and unowned things, mines and mountains and the sap of Amazonian trees and the "infinite number of species of animals which have never been seen or known by men" (this was the expression of the sprite, in Leopardi's dialogue of 1827). ${ }^{61}$ The economists and others who were engaged in the evaluation-we might call them a virtual "Bureau of Environmental Value" - would be practical individuals. They would wish to include, in the photograph, only the things which contributed to production, or which were likely to contribute to production in the future; they would also seek to include, in this photograph of things which were uneconomic-in the sense that either the things or the services of the things were unowned, or difficult to

58 On the environment and property rights which are of interest in more than one nation, see Nalebuff, "On a Clear Day, You Can See the Coase Theorem”, 35, 44-6.

59 Hayek, "Maintaining Capital Intact: A Reply", 279; idem, "Scientism and the Study of Society", Economica new series, 9/35 (Aug. 1942), 268-9; idem "Scientism and the Study of Society, Part II", Economica new series, 10/37 (Feb. 1943), 34-63, 40-41, 47, 57; "Scientism and the Study of Society, Part III", Economica new series, 11/41 (Feb. 1944), 27-39, 31.

60 F. A. Hayek, "The Use of Knowledge in Society", American Economic Review 35/4 (Sept. 1945), 519-30, 521.

61 It would "reveal, in addition to the durable wealth ... trainloads of meat, eggs and milk in transit ... Even the supplies on the table of a man bolting his dinner would find a place". Irving Fisher, "Senses of 'Capital", Economic Journal 7/26 (June 1897), 199-213, 19. 
own-only the things which were almost economic, or which had almost-market substitutes; they would exclude things that contributed to consumption, or wellbeing, without contributing to the production of well-being. (Mineral deposits, for example, were "instrumental productive capacity", in Solow's distinction, while "natural beauty ... [was] more a question of direct consumption". ${ }^{62}$ )

When the Bureau had decided on its retouched photograph, its inventory of physical stocks and flows, it would have to produce a second instantaneous photograph, of the values of all the things, a photograph with price labels stuck all over it. ${ }^{63}$ But this procedure, or this sequence of representations, would always, in Hayek's terms, be a view from outside. It raises the political and epistemological questions with which Hayek was later so vexed, about the foundations of social knowledge, and the despotism of experts. It also raises, in a new form, the capitaltheoretic questions about expectations of 1941-2. The values of individuals change over time, and with new information. They are based, often, on false information. They may be based, too, on information which would be thought of by experts as frivolous. There is unanticipated technical change, or there are unanticipated changes in values; the publication of the Bureau's own reports is among the events which affect expectations of future production. The preferences of individuals include preferences over the sorts of natural things to be included in the Bureau's inventory, and the sorts of procedures by which they are to be evaluated.

The third objection to Pigou, or Hicks's objection about the identity of the valuers, and the "purpose for which the definition [or the valuation] is wanted", was the most pointed of all, in relation to environmental capital. ${ }^{64}$ Pigou's initial interest in maintaining capital intact had to do with the concept of income, and income tax. It was not entirely clear what Hayek's interest was - some sort of self-evaluation, perhaps, on the part of a group of businessmen, concerned to judge whether one of their members "has done his best", or "as well in this effort as he might have done". ${ }^{65}$ But Pigou's interest had clearly evolved by 1941-2, as Hicks discerned, to a concern with net social income, or the income of nations. The evaluation of national or social income was Hicks's concern as well, in the

62 Solow, "On the Intergenerational Allocation of Natural Resources".

63 As in Hegel's description of the "museum" of science: "What results from this method of labelling all that is in heaven and earth ... is nothing less than 'a report as clear as noonday' on the universe as an organism, viz. a synoptic table like a skeleton with scraps of paper stuck all over it, or like the rows of closed and labelled boxes in a grocer's stall". G.W.F.Hegel, Phenomenology of Spirit (1807), trans. A. V. Miller (Oxford: Oxford, 1977), 31.

64 "It is not profitable to embark on the fine analysis of a definition unless we have decided on the purpose for which the definition is wanted." Hicks, "Maintaining Capital Intact: A Further Suggestion", 175.

65 Hayek, "Maintaining Capital Intact: A Reply", 279. 
wartime years during which the modern "international" systems of national accounts were developed.

It is Pigou's interests in net social income which have survived, for the most part, in the late twentieth-century environmental-cum-economic accounts. The "purpose for which" the accounts were wanted was to serve as a reminder of the future, or a way of remembering about resources — for "scorekeeping or management". But the question of who it is is who was to do the evaluating, and the purpose for which the evaluation was wanted, was of political importance, even in the administrative universe of the Bureau of Environmental Value. Capital-like things were bundles of property rights, in the description of Pigou's critics, and the "satellite accounts" of the Bureau were likely to be of the greatest importance for the expectations of the owners of these heterogeneous things, and these heterogeneous bundles. Penalty taxes, as James Buchanan pointed out in a commentary on Coase, were changes in property rights. ${ }^{66}$ They might even (to use Paul Samuelson's language, in relation to the services of capital goods), be "suspected' in advance", thereby inducing "anguish and revaluations" on the part of the owners of mountains, fishing vessels and undersea diamonds. ${ }^{67}$

So there was a need, even in the neo-Pigovian system, for a political economy of environmental valuation, in the limited sense of late twentieth-century economics, of uncovering the secret self-interest of public officials, and of the enterprises with interests in influencing the officials' "scorekeeping". There was a need, too, for a theory of the state, in Buchanan's expression, and even for a theory of international society. ${ }^{68}$ The descriptions of government in the earliest summaries of the UK and US accounts systems established in the 1940 s were almost comically unselfconscious about the political process; the state was a "simple extension of individual households" which undertakes "agency activities for the body of consumers as a whole", or an agency which provides output "on behalf of the community as a whole, which it has been found better to secure collectively rather than individually". ${ }^{6}$ But the work of the Bureau of Environmental Value, with its scorekeeping (or exhortation) and its management (or regulation), would not be entirely modest. It would not be a "coercive legal device for directing self-interest into social channels", perhaps, as in the expression

66 James Buchanan, "The Coase Theorem and the Theory of the State", Natural Resources Journal 13/4 (Oct. 1973), 579-94.

67 Paul A. Samuelson, “The Evaluation of 'Social Income': Capital Formation and Wealth", in The Collected Scientific Papers of Paul A. Samuelson, vol. 1 (Cambridge, MA, 1966), 292-324, 303.

68 Buchanan, "The Coase Theorem and the Theory of the State", 579.

69 Richard Stone, The Role of Measurement in Economics (Cambridge, 1951), 43, 56; US Department of Commerce, National Income (Washington, DC, 1954), 38. 
of Pigou's that his critics so disliked. But it would be a "method of social control", in Hayek's own expression, or a series of public numbers, "inducements which will make the individuals do the desirable things without anyone having to tell them what to do". ${ }^{70}$

\section{HISTORY AND IMAGINATION}

To return, in conclusion, to the varieties of environmental and intellectual history, I hope I have been able to show that at least some of the controversies in the history of economic thought, and even in the "highest" or most abstract economic thought, are of interest in relation to the history of the environment, and that the economic theory of capital is intertwined in elaborate and to some extent counterintuitive ways with political ideas about the state. It has been a history of the destinies of intellectuals (or economists), and also of the destinies of ideas; of the changing relationships in which the high economic thought of theorists is influenced by, as well as influencing, the medium or intermediate economic thought of tax specialists and directors of statistical offices, and the low economic thought of the many more millions of people who are interested in sustainability and sustainable development.

Environmental history is the history of the entities and ideas that are everywhere, and all around: all around human individuals, in particular. It is not a history of something like a layer of wool, which surrounds the earth. It is a history, rather, of the relationships between people and things, which are in part relationships of ideas. The history of environmental policy is, as Charles Rosenberg has said of the history of health policy, a neglected and promising area for research. ${ }^{71}$ It is connected, in the story with which I have been concerned, to another neglected area-that of the history of national and international economic statistics, or accounts, statistical systems which were invented, in their contemporary form, amidst the maximally national purposes of the 1940s, and which have been adapted, intermittently, to the circumstances of transnational politics and transnational exchanges. It is also connected to the amazing late twentieth-century story of the new transnational age of words, or numbers; of non-governmental organizations, expert committees, "UN words", sustainability indicators and Namibia's or Australia's augmented capital accounts; of "big, impractical, words", and also big, impractical, international numbers.

\footnotetext{
70 Pigou, The Economics of Welfare, 129; F. A. Hayek, The Road to Serfdom (Chicago, 1972; first published 1944), 75; Hayek, "The Use of Knowledge in Society", 527.

71 Charles E. Rosenberg, Our Present Complaint: American Medicine, Then and Now (Baltimore, 2007), 186.
} 
I would even like to suggest that these historical stories can illuminate our own (our 58,000,000 million own) environmental ideas. The idea of environmental capital has in the economists' stories been identified as a "reminder", a "score", or a "rule of thumb". It is a reminder, in particular, of the future, and of the unsold (or the unsaleable.) There is something odd, of course, about the conception that in order to remind people of something, or of its value, one should describe it as being like a capital asset. As one of the theorists of environmental capital concluded in 2007, "the macroeconomic history of nations looks very different when Nature is included as a capital asset in production". ${ }^{2}$ It would be a history, at least, with very little space for the imagination of a different and distant future. ${ }^{73}$ There is something odd, too, about the ingenuous descriptions which economists, at least since Pigou, have given of the relationship between economic theory, the expanding industry of applied economics and economic consultancies, and economic (or environmental) policy.

But the reminder of the unreproducibility of resources constituted by environmental-cum-economic accounts, and by the large round numbers of "Green NNP", has at the same time been a powerful impetus to environmental protection and conservation. The US Department of Commerce's integrated environmental accounts were suspended in legislation introduced, in 1994, by Congressman Alan B. Mollohan of West Virginia, who in his own description "advocates a 'common-sense' approach to environmental regulations that impact coal [and] opposes politically driven air requirements" ${ }^{74}$

The enterprise of maintaining (environmental) capital intact is a Pigovian and dirigiste enterprise, which is susceptible of Hayekian (or libertarian) apprehensions. It is a "liberal" and a "conservative" cause..$^{75}$ It is an objective to be attained through information, regulation, taxation, or the politics of

72 Partha Dasgupta, "Nature and the Economy", Journal of Applied Ecology 44/3 (June 2007), $475-87,487$.

73 On the politics of energy and climate change, see Dipesh Chakrabarty, "The Climate of History: Four Theses", Critical Inquiry 35 (Winter 2009), 197-222; and Timothy Mitchell, "Carbon Democracy", Economy and Society 38/3 (Aug. 2009), 399-432.

74 CONFERENCE REPORT ON 4603 (House of Representatives-August 16, 1994), TITLE II-DEPARTMENT OF COMMERCE, Amendment No. 69, sponsored by Rep. Alan B. Mollohan (Dem., W.Va): "The conferees understand that there has been considerable debate over the years as to the objectivity, methodology, and applicability of 'Integrated Environmental-Economic Accounting' or 'Green GDP' ... The conferees expect BEA to suspend development of Phase II of this initiative." Library of Congress, http://thomas.loc.gov/cgi-bin/query/F?r103:1:./temp/ r103YsjkSe:e116248; and see http://www.house.gov/mollohan/bio.htm, accessed 30 Oct. 2008.

75 On liberalism and conservatism in the economic thought of the 1930s and 1940 see Angus Burgin, "The Radical Conservatism of Frank H. Knight”, MIH 6/3 (Nov. 2009), 513-38. 
environmental numbers. It seeks to convince (or to "nudge") with numbers. ${ }^{76}$ It is a governance, like so much of environmental policy, of "suitably chosen experts". But it is a profoundly un-Hayekian enterprise, too, in the sense that the individual knowledge which Hayek opposed to the centralized and systemic knowledge of the state was knowledge of the local and fleeting, and the knowledge which is so important in environmental politics is also individual knowledge, or lack of knowledge, of immense systems and the infinite future.

The story, in the end, has been about the different ways in which different kinds of individuals, economists and non-economists, Namibians and English and Austrians, individuals in the past and the future individuals they imagined, assigned names and numbers and property rights to different kinds of things. It is inspired, in this respect, by one of the greatest works of environmental history, for the different ways in which twentieth- and twenty-first-century individuals thought about the world of things are as diverse, now, as the ways of buying and selling and gathering and naming which William Cronon described in Changes in the Land: a world which was widened by Cronon to include "rocks, trees, and soil; plants and animals, both wild and domestic; insects; and even invisible ... microorganisms", and which is also, now, a worldwide world. ${ }^{77}$

76 On the "libertarian paternalism" of the nudge, in which the efficient operation of institutions designed by well-informed "choice architects" is propitious "not for bigger government, just for better governance", and in which "it helps to think about the environment as the outcome of a global choice architecture system", see Richard H. Thaler and Cass R. Sunstein, Nudge: Improving Decisions about Health, Wealth and Happiness (New Haven, 2008), 11-14, 185. The sinister-sounding Bureau of Environmental Value would be more libertarian and less paternalistic, in these terms, to the extent that it disclosed the information on the basis of which it arrived at its large green numbers.

77 John Demos, "Foreword", in William Cronon, Changes in the Land: Indians, Colonists, and the Ecology of New England, rev. edn (New York, 2003), xiii. 